\title{
Significance Important of Fruit Character for Some Asteraceae Species in Identification and Differentiation Level
}

\author{
Dalia Goda Ibrahim Gabr
}

Department of Basic Science, Faculty of Education, Imam Abdulrahman Bin Faisal University, Saudi Arabia 7322 Amir Ib Fahira - Ar Rawdah, Unit No. 3, Ad /Dammam 32256 - 3210, Kingdom of Saudi Arabia

DOI: $\underline{\text { 10.36348/SJLS.2019.v04i08.003 }}$ | Received: 21.09.2019|Accepted: 28.09.2019| Published: 30.09 .2019

*Corresponding author: Dalia Goda Ibrahim Gabr

\section{Abstract}

Achene and pappus macro and micro-morphological characters for 10 species belong to two sub-family of Asteraceae from eastern region of Saudi Arabia to evaluate the application of this character in the identification and differentiation level by using light microscope (LM) and scanning electron microscope (SEM). The achene morphological characters as, size, shape, color, texture, ridges, base, achene coat and pappus characters are done. The achene coat pattern sculpture recorded 6 types; striate, tuberculate, granulate, sulcate, irregular reticulate and reticulate-rugose, the main types were reticulate. The pappus type's recorded three types; scabrous barbellate bristles, scabrous subulate scales free and capillary barbelllate, the main types were scabrous barbellate bristles found in seven studied species. The result for this study supports the use of achene morphological characters for identification and differentiates of different related species but cannot be used for taxonomical levels for the different tribes.

Keywords: Achene characters, Scanning Electron Microscope, Asteraceae, Eastern region of Saudi Arabia.

Copyright @ 2019: This is an open-access article distributed under the terms of the Creative Commons Attribution license which permits unrestricted use, distribution, and reproduction in any medium for non-commercial use (NonCommercial, or CC-BY-NC) provided the original author and source are credited.

\section{INTRODUCTION}

The family Asteraceae (Compositae) is a very large cosmopolitan family. It is represented by 1,620 genera and around 23,600 known species [1], divided under 10 subfamilies and 35 tribes [2,3]. Asteraceae in Saudi Arabia is represented by 61 genera and 120 species according to [4]. In the eastern region of Saudi Arabia there are 43 general and 66 species [5].

The fruit of Asteraceae are technically called as cypsela or achene, which develops from bicarpellary, syncarpus, epigynous, one chambered, one ovuled ovary with basal placentation. Most achene have appendage called pappus; the most recent workers have adopted the view that the pappus is a modified calyx [68].

Micro-morphological characters of the fruit and seed coat play important role in taxonomy and evolutionary studies were used as characters for species identification [9].

Cypsela or achene features are very helpful, for the separation of taxa, when flowering stage is unavailable [10]. Also, the pappus is a taxonomically important and useful organ in Asteraceae [11]. Cypsela or achene study has been utilized by many authors successfully for the delimitation of genera and species within the family Asteraceae from different parts of the world such as; [12] study macro and micromorphological characters of cypsela in seven species of tribe Anthemideae [13] study the achene characters of 11 species representing five genera of Anthemideae [14] study the data on morphological, histological and scanning electron microscopic for cypsela of 23 species belonging to nine sub-tribes of the tribe Heliantheae [15] study the structures of pappus in 52 species belong to 30 genera of four subfamilies of Asteraceae by using light and scanning electron microscope [16] study the cypsela morphology for five species of tribe Mutisieae from Pakistan[17] study achene macro and micromorphological characters for five species belong to Senecio jacobaea group [18] study the cypsela morphology of 30 taxa of Lactuca L., Cicerbita Wallr. and Prenanthes L. from Pakistan [19] study the achene wall anatomy and surface sculoturing of 12 taxa belong to genus Launaea Cass from Egypt [20] study the achene surfaces of 31 taxa belonging to the genus Centaurea L. from Turkey [21] study achene surface sculpturing and pappus ultrastructure of 26 Crepis taxa from Turkey and [22] study the achene macro- and micromorphologies characters for 22 taxa of the genus Cota from Turkey by using stereo and scanning electron 
microscope (SEM). Some studies on family Asteraceae growing on Saudi Arabia are done such as [23-27]. But the achene macro and micro-morphological studies for the Saudi Arabia Asteraceae species has not yet been conducted. Also, the most of achene studied species are studied for the first time, so the objective of this study are to describe and compare the achene and pappus macro and micro-morphological characters for some species belong to two sub-family of Asteraceae from eastern region of Saudi Arabia to evaluate the application of this character in the identification and differentiation level.

\section{MATERIAL AND METHODS}

The present study included achene of 10 species of family Asteraceae belong to two sub-families according to [3], collected fresh from different localities from Dammam city in eastern region of Saudi Arabia (Table 1). The materials studied were identified according to the plant key of [5, 28]. For fruit morphology, five to seven achenes were investigated to record their dimensions, shape, color, size, pappus characters and surface texture by using Olympus Bx53. light microscope (LM). Details of achene sculpture and pappus type were examined by scanning electron microscope (SEM) with the use of FEI, ISPECT S50 (Czech Republic). SEM was operated at $20 \mathrm{kV}$ with working distance $10 \mathrm{~mm}$. Long and high magnification was performed to capture the recognized features of the specimen. The terminology of [17, 29-31] was adopted to describe the SEM aspects of the achene coat, and the terminology of [15] for pappus types.

Table-1: Collection data of the studied species of family Asteraceae from Eastern Region of Saudi Arabia, Sub-family according to Panero \& Funk, 2002

\begin{tabular}{|c|l|l|}
\hline Sub-Family & \multicolumn{1}{|c|}{ Species } & \multicolumn{1}{|c|}{ Locality and date } \\
\hline \multirow{4}{*}{ Asteroideae } & Conyza linifolia (Wild) Tackh & Rayan - Dammam, 1/2017 \\
\cline { 2 - 3 } & Pluchea dioscoridis (L.) DC. & King Khaled street - Dammam, 5/2017 \\
\cline { 2 - 3 } & Senecio glaucus L. & Rayan - Dammam, 4/2017 \\
\cline { 2 - 3 } & Ifloga spicata (Forssk.) Sch.- Bip. & Rayan - Dammam, 4/2017 \\
\cline { 2 - 3 } Cichorioideae & Eclipta alba (L.) Hassk. & Rayan - Dammam, 4/2017 \\
\hline & Launaea mucronata (Forssk.) Muschl & Rayan - Dammam, 3/2017 \\
\cline { 2 - 3 } & Launaea nudicaulis (L.) Hook.f. & Rayan - Dammam, 3/2017 \\
\cline { 2 - 3 } & Launaea procumbens (Roxb.) Romayya \& Rajg. & Rayan - Dammam, 3/2017 \\
\cline { 2 - 3 } & Sonchus oleraceus L. & Rayan - Dammam, 3/2017 \\
\cline { 2 - 3 } & Reichardia tingitana (L.) Roth. & Rayan - Dammam, 3/2017 \\
\hline
\end{tabular}

\section{RESULTS}

The achene morphological characters, pappus and achene sculpture of the studied species are studied by light and scanning electron microscope and the observation are summarized in table $2 \& 3$ and plate $1 \&$ 2 .

Conyza linifolia (Wild) Tackh: Achene is oblong, yellowish green with size $1.8 \mathrm{~mm}$ long and 0.35 $\mathrm{mm}$. width. The texture is sparsely hair with two types of non-glandular hair scattered on the surface and notridged. The achene base is tapered, and the apex ended by pappus element. Pappus are persistent, limited in number, connate at the base, whitish with $3.8-5 \mathrm{~mm}$. long and have scabrous barbellate bristles type. The achene coat pattern sculpture is striate with thin, line, convex anticlinal wall and concave, papillate periclinal wall.

Pluchea dioscoridis (L.) DC.: Achene is oblong, light brown with size $0.9 \mathrm{~mm}$ long and $0.1 \mathrm{~mm}$. width. The texture is not-ridged and has non-glandular hair with short basal cell and long acute apical cell scattered on the surface. The achene base is rotund, and the apex ended by pappus element. Pappus are persistent, limited in number, un-connate at the base, white with 5-5.5 $\mathrm{mm}$. long and have scabrous subulate scales free type. The achene coat pattern sculpture is striate with thick, line, convex anticlinal wall and grooved, smooth periclinal wall.

Senecio glaucus L.: Achene is elliptic, brown with size $1.9 \mathrm{~mm}$ long and $0.35 \mathrm{~mm}$. widths. The texture is ridged with four primary ridged and pupsent with non-glandular long blunt apical cell on the entire surface. The achene base is tapered, and the apex ended by pappus element. Pappus are deciduous, unlimited in number, un-connate at the base, white with $7.8-8 \mathrm{~mm}$. long and have scabrous barbellate bristles type. The achene coat pattern sculpture is tuberculated with thick, wavy, convex anticlinal wall and grooved, tuberculate periclinal wall.

Ifloga spicata (Forssk.) Sch.- Bip.: Achene is oblong, yellowish green with size $0.6 \mathrm{~mm}$ long and 0.25 $\mathrm{mm}$. width. The texture is not-ridged and glanded with unicellular multi-seriate papillose cell scattered on all the surface. The achene base is rotund, and the apex ended by pappus element. Pappus are deciduous, unlimited in number, connate at the base, white with 3 $4 \mathrm{~mm}$. long and have scabrous barbellate bristles type. The achene coat pattern sculpture is granulating with thin, undulate convex anticlinal wall and concave tuberculate periclinal wall. 
Eclipta alba (L.) Hassk: Achene is long ovate, winged, brown with size $2.8 \mathrm{~mm}$ long and $1.4 \mathrm{~mm}$. width. The texture is tuberculated and not-ridged. The achene base is truncate. Pappus is absent. The achene coat pattern sculpture is irregular reticulate with thin, wavy raised anticlinal wall and grooved papillate periclinal wall.

Launaea mucronata (Forssk.) Muschl: Achene is oblong, brown with size $5 \mathrm{~mm}$ long and $0.35 \mathrm{~mm}$. width. The texture is tuberculated and ridged with four ridged $(2,2)$. The achene base is truncate, and the apex ended by pappus element. Pappus are persistent, unlimited in number, connate at the base, white with 9.5 - $10 \mathrm{~mm}$. long and have capillary barbellate type. The achene coat pattern sculpture is sulcate with thick, wavy raised anticlinal wall and convex striated periclinal wall.

Launaea nudicaulis (L.) Hook.f: Achene is fusiform, yellowish brown with size $1.1 \mathrm{~mm}$ long and $0.2 \mathrm{~mm}$. width. The texture is smooth and ridged with four primary ridged. The achene base is tapered, and the apex ended by pappus element. Pappus are deciduous, unlimited in number, connate at the base, white with 7.5 - $8 \mathrm{~mm}$. long and have scabrous barbellate bristles type. The achene coat pattern sculpture is irregular reticulate with thin, undulate convex anticlinal wall and concave papillate periclinal wall.

Launaea procumbens (Roxb.) Romayya \& Rajg.: Achene is oblong, winged, white with size $3 \mathrm{~mm}$ long and $1.4 \mathrm{~mm}$. width. The texture is tuberculated and ridged with eight $(4,4)$ ridged. The achene base is truncate, and the apex ended by pappus element. Pappus are deciduous, unlimited in number, connate at the base, white with 4.4 - $5 \mathrm{~mm}$. long and have scabrous barbellate bristles type. The achene coat pattern sculpture is reticulate-rugose with thin, undulate raised anticlinal wall and concave smooth periclinal wall.

Sonchus oleraceus L.: Achene is fusiform, brown with size $3 \mathrm{~mm}$ long and $2 \mathrm{~mm}$. widths. The texture is tuberculated and ridged with eight $(4,4)$ ridged. The achene base is tapered, and the apex ended by pappus element. Pappus are deciduous, unlimited in number, connate at the base, white with $6.5-7 \mathrm{~mm}$. long and have scabrous barbellate bristles type. The achene coat pattern sculpture is reticulate-rugose with thick, wavy raised anticlinal wall and concave smooth periclinal wall.

Reichardia tingitana (L.) Roth: Achene is elliptic, brown with size $3 \mathrm{~mm}$ long and $1.3 \mathrm{~mm}$. width. The texture is tuberculated and ridged with ten $(5,5)$ ridged. The achene base is rotund, and the apex ended by pappus element. Pappus are deciduous, unlimited in number, un-connate at the base, white with $6.5-7 \mathrm{~mm}$. long and have scabrous barbellate bristles type. The achene coat pattern sculpture is reticulate-rugose with thick, wavy raised anticlinal wall and grooved smooth periclinal wall.

The key: The macro and micro-morphological data obtained and recorded in Tables $2 \& 3$ were used to construct the following bracketed key to the ten species of Asteraceae that could be helpful in the confirmation of their identify.

1.Achene long ovate and pappus absent..... Eclipta alba

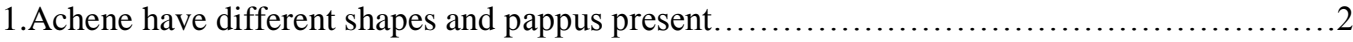

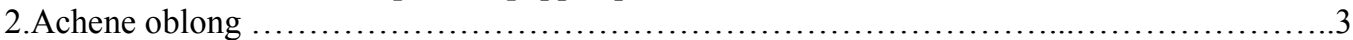

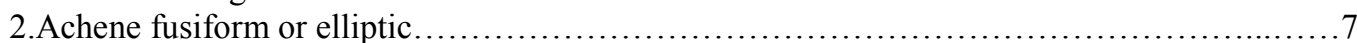

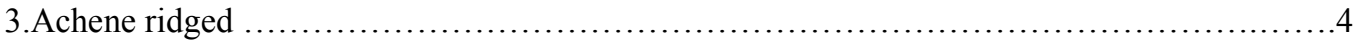

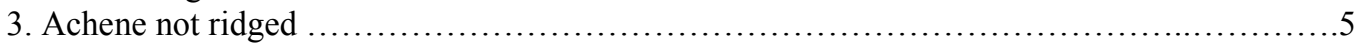

4. Achene brown, winded, have four ribs and sulcate achene coat sculpture. Pappus persistent and have capillary barbellate type................................ Launaea mucronata

4.Achene white, not winged, have eight ribs and reticulate-rugose achene coat sculpture. Pappus deciduous and have scabrous barbellate bristles type ................. Launaea procumbens

5.Achene glanded texture, achene coat sculpture is granulate and pappus un-limited in number Ifloga spicata

5.Achene sparsely hairy and have striate achene coat sculpture. Pappus limited in number........6

6.Achene yellowish green, tapered at base, pappus whitish, connate and have scabrous barbellate bristles type Conyza linifolia

6.Achene light brown, rotund base, pappus white, un-connate and have scabrous subulate scales free Pluchea dioscoridis

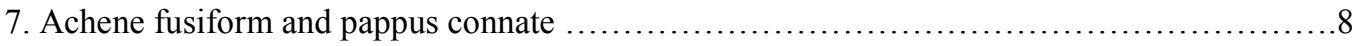

7.Achene elliptic and pappus un-connate ......................................... 9

8.Achene yellowish brown, smooth texture, have four ribs and irregular reticulate achene coat sculpture................................................... Launaea nudicaulis

8.Achene brown, tuberculate texture have eight ribs and reticulate-rugose achene coat sculpture

9.Achene pupscent, have four ribs, tapered base and tuberculate achene coat sculpture 
9.Achene tuberculate, have ten ribs, rotund base and reticulate-rugose achene coat sculpture Reichardia tingitana

Table-2: Comparative observations on achene morphology of the studied species of Asteraceae

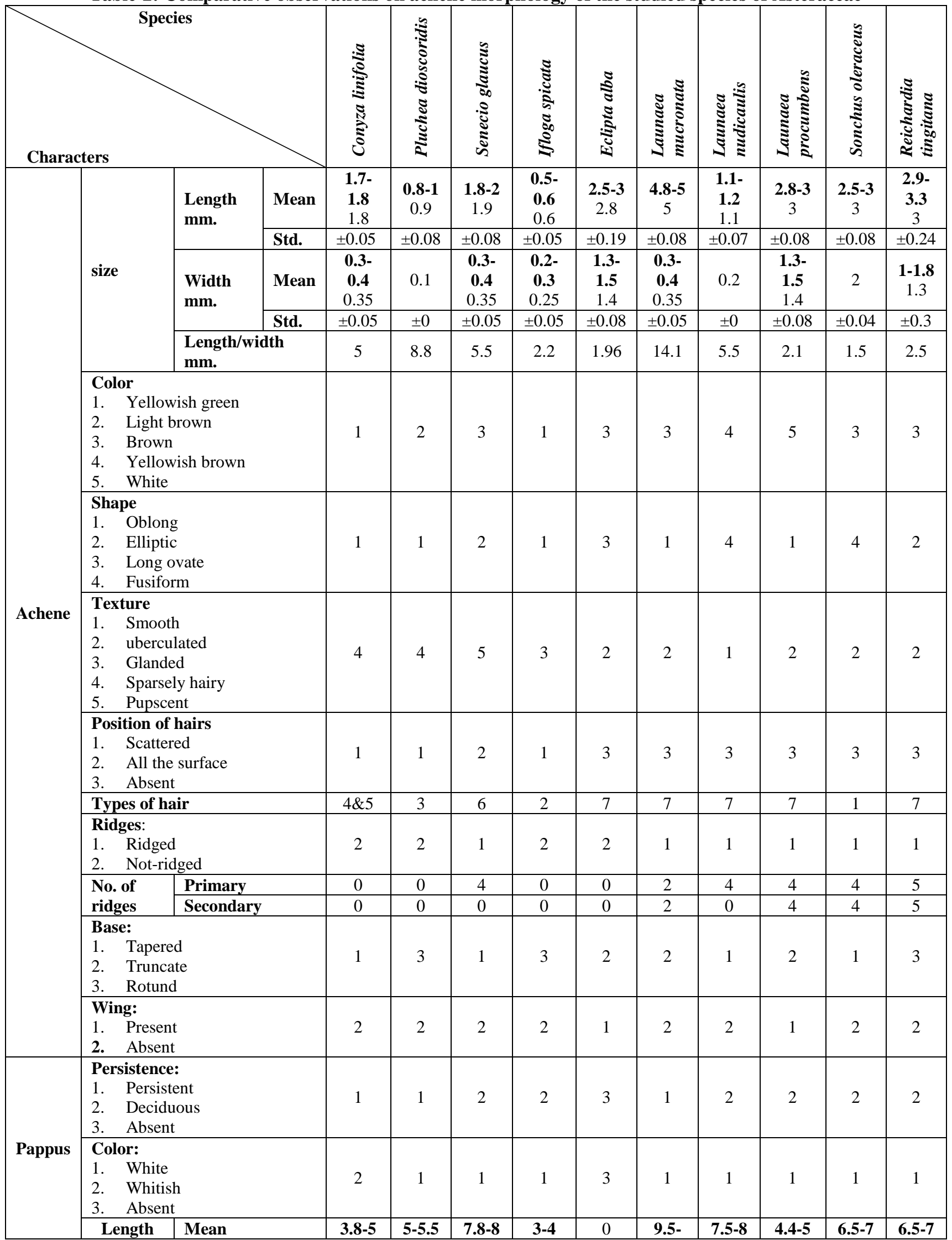




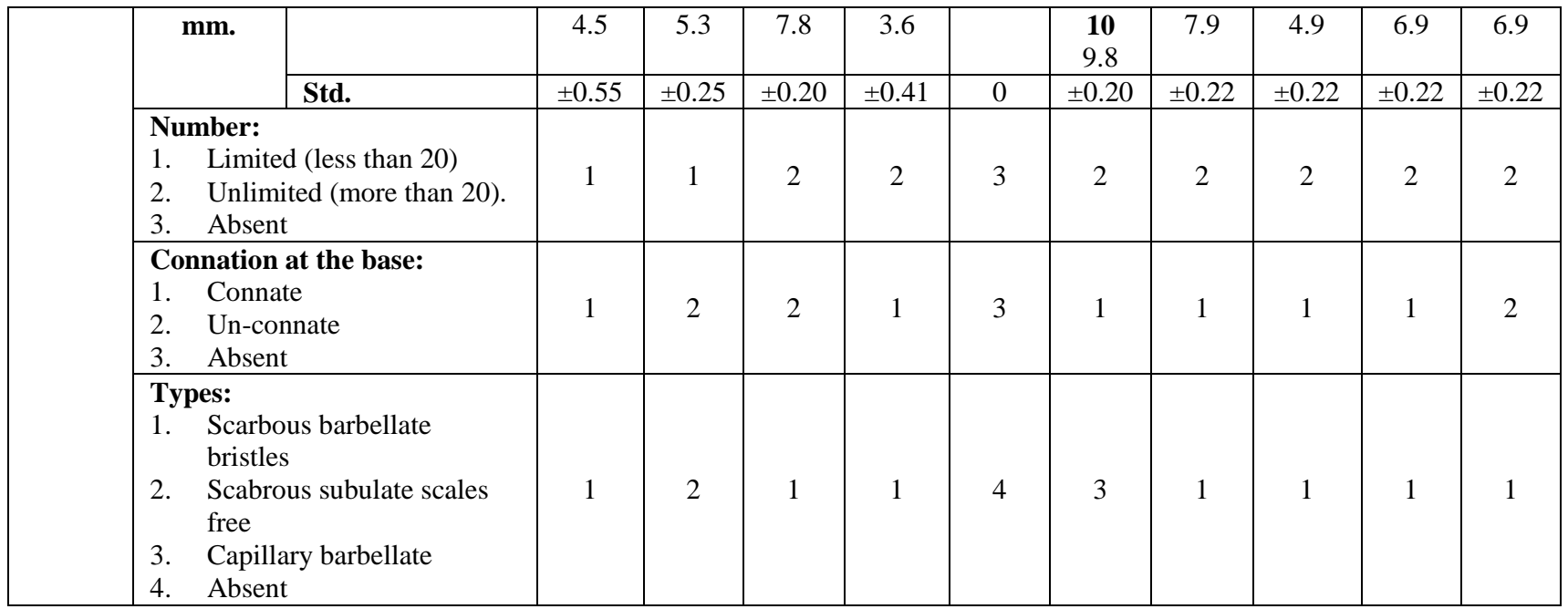

\section{Types of hair}

1-Unicellular papillose cell

2-Unicellular multi-seriate papillose cell

3-Non-glandular with short basal cell and long acute apical cell

4-Non-glandular with two basal cell and long acute apical cell
5-Non-glandular with two basal cell and long acute biseriate apical cell

6-Nonglandular with long blunt apical cell

7-Absent

Std. = "standard deviation"

Table-3: Comparative observations on achene coat micrography of the studied species of Asteraceae

\begin{tabular}{|c|c|c|c|c|c|c|c|c|c|c|c|}
\hline \multicolumn{12}{|c|}{ (2) } \\
\hline \multicolumn{2}{|c|}{ Characters } & 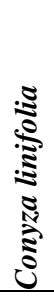 & 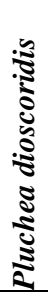 & 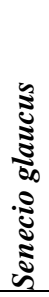 & 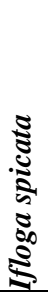 & 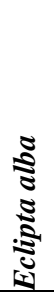 & 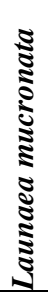 & 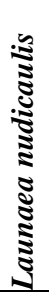 & 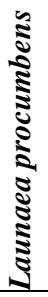 & 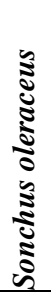 & 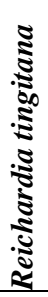 \\
\hline \multicolumn{2}{|c|}{\begin{tabular}{ll}
\multicolumn{2}{l}{ Achene coat pattern sculpture: } \\
1. & Striate \\
2. & Tuberculate \\
3. & Granulate \\
4. & Sulcate \\
5. & Irregular reticulate \\
6. & Reticulate-rugose \\
\end{tabular}} & 1 & 1 & 2 & 3 & 5 & 4 & 5 & 6 & 6 & 6 \\
\hline \multirow{3}{*}{ 逽 } & $\begin{array}{l}\text { Shape: } \\
\text { 1. Line } \\
\text { 2. Wavy } \\
\text { 3. Undulate } \\
\end{array}$ & 1 & 1 & 2 & 3 & 2 & 2 & 3 & 3 & 2 & 2 \\
\hline & \begin{tabular}{l}
\multicolumn{3}{l}{ Thickness: } \\
1. $\quad$ Thin \\
2. $\quad$ Thick
\end{tabular} & 1 & 2 & 2 & 1 & 1 & 2 & 1 & 1 & 2 & 2 \\
\hline & $\begin{array}{l}\text { Level: } \\
\text { 1. } \quad \text { Convex } \\
\text { 2. } \quad \text { Raised } \\
\end{array}$ & 1 & 1 & 1 & 1 & 2 & 2 & 1 & 2 & 2 & 2 \\
\hline \multirow{2}{*}{ 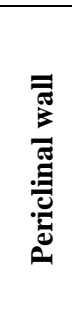 } & \begin{tabular}{ll}
\multicolumn{2}{ll}{ Level: } \\
1. & Concave \\
2. & Grooved \\
3. & Convex
\end{tabular} & 1 & 2 & 2 & 1 & 2 & 3 & 1 & 1 & 1 & 2 \\
\hline & \begin{tabular}{ll}
\multicolumn{2}{l}{ Texture: } \\
1. & Smooth \\
2. & Tuberculate \\
3. & Striate \\
4. & Papillate
\end{tabular} & 4 & 1 & 2 & 2 & 4 & 3 & 4 & 1 & 1 & 1 \\
\hline
\end{tabular}



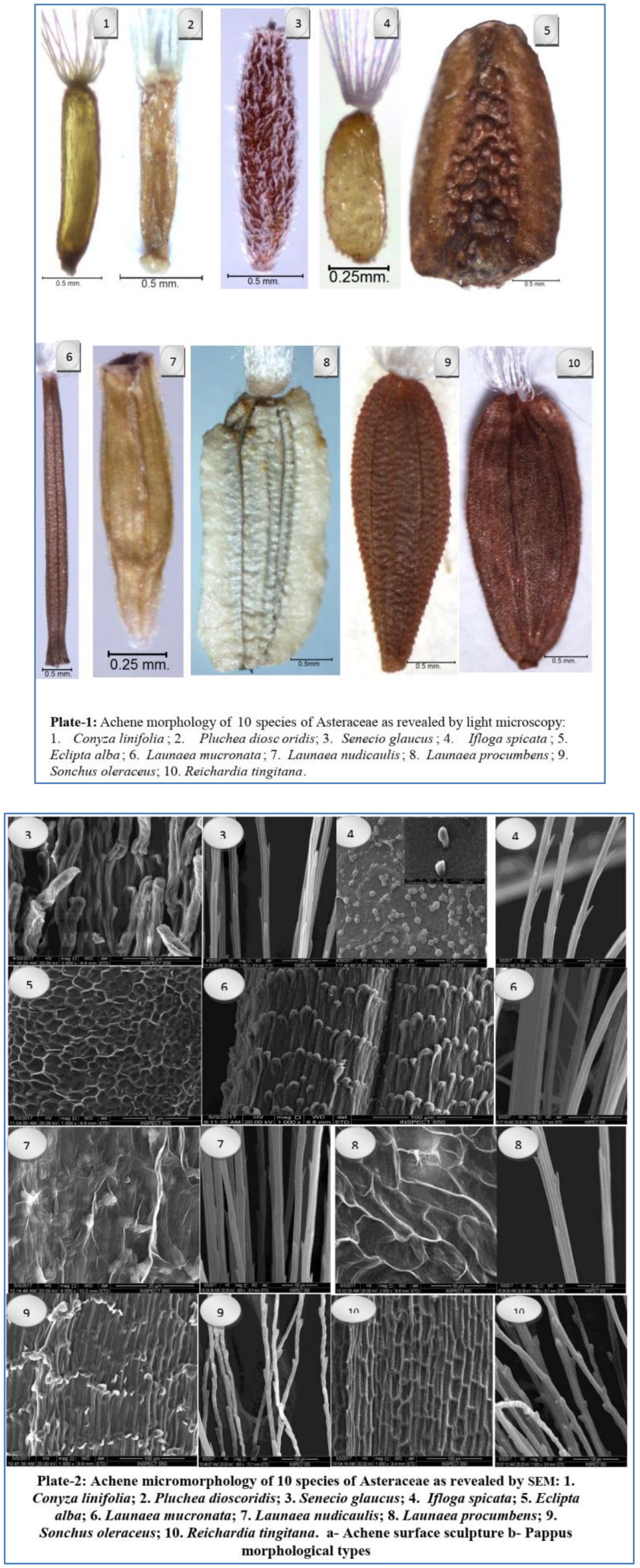


\section{DISCUSSION}

Asteraceae is one of the most important family and easy to recognize family by its characters of its inflorescence [32]. In the absence of flower or in some species which have almost the same characters of flowers the fruit or seed characters play the main role for identification and differentiation between these species. The present study shows a wide variation in macro and micro-morphological characters of achene for the studied species of Asteraceae, the size of achene differs significantly from $0.6 \mathrm{~mm}-5 \mathrm{~mm}$ long and from $0.1 \mathrm{~mm}-1.4 \mathrm{~mm}$. widths. The color of the fruit or seed play important taxonomical role but must be in stage of full maturation since the color changes with the degree of maturation [12]. In this study the studied species recorded three main color ranged from white in Launaea procumbens, yellowish green in Conyza linifolia and Ifloga spicata and brown with different degree in the reminder species. The shape of the achene in the studied species recorded four types; oblong is the main shape present in five species, elliptic found in two species, long ovate in one species and fusiform in two species. The texture of the surface of achene ganged from smooth, glanded, tuberculated, and sparsely hairy and pupscent. The achene may be ridged or not ridged, the number of primary and secondary ridges have important role for distinguish between different studied species, this agree with $[12,19]$. The base of achene also has important role in taxonomy; in the present study recorded three types ranged from, tapered, truncate and rotund.

The achene coat pattern sculpture has an important role for the differentiation between the related species. In this study the studied species recorded 6 types of achene coat pattern sculpture; (1) Striate with line convex anticlinal wall and concave papillate Periclinal wall in Conyza linifolia or with concave smooth Periclinal wall in Pluchea dioscoridis. (2) Tuberculate with wavy convex anticlinal wall and grooved tuberculate Periclinal wall in Senecio glaucus. (3) Granulate with undulate convex anticlinal wall and concave tuberculate Periclinal wall in Ifloga spicata.(4) Sulcate with wavy raised anticlinal wall and convex striate Periclinal wall in Launaea mucronata.(5) Irregular reticulate with wavy convex anticlinal wall and grooved papillate Periclinal wall in Eclipta alba or Irregular reticulate with undulate convex anticlinal wall and concave papillate Periclinal wall in Launaea nudicaulis. (6) Reticulate-rugose with undulate or wavy raised anticlinal wall and concave or grooved smooth Periclinal wall in Launaea procumbens, Sonchus oleraceus and Reichardia tingitana.

The characters of pappus are significantly differing in the studied species so, these pappus microcharacters can be used as additional data to support the morphological separation of these closely related species [21]. The persistence of pappus, color, length, number, connation at the base and the types are the characters of pappus for the studied species. The most important characters for identification and separation are the types of pappus. In the present study the pappus recorded three types; (I), Scabrous barbellate bristles present in Conyza linifolia, Senecio glaucus, Ifloga spicata, Launaea nudicaulis, Launaea procumbens, Sonchus oleraceus and Reichardia tingitana. (II) Scabrous subulate scales free in Pluchea dioscoridis and (III) Capillary barbellate in Launaea mucronata. The results of this study support that the macro and micro-morphological characters of the achene for family Asteraceae have important role in identification and differentiation between the associated species, this agree with [14,33-37] and cannot be used for the taxonomy in tribal level and this agree with [38].

\section{CONCLUSION}

The achene morphological characters as, size, shape, color, texture, ridges, base and achene coat micro-morphological characters are very significant characters of achene which can be used for identification and differentiate between the associated species. Also, the characters of pappus as, persistence, color, length, number, connation at the base and the types can be used as supported data for identification and differentiate of different species, but this character cannot be devised for taxonomical levels for the different tribes.

\section{Significance statement}

The achene features are very helpful toll for the identification and separation of species or taxa, when flowering stage is absent. For that and since the most of achene studied species are studied for the first time, so the objective of this study is to describe and compare the achene and pappus macro and micromorphological characters which helped for identification and differentiation between this species and support the important of these characters.

\section{ACKNOWLEDGEMENTS}

Author is grateful to the staff of Institute for Research and Medical Consultation (IRMC) in the University of Imam Abdulrahman Bin Faisal for carry out the Scanning Electron Microscope (SEM). Also, I would like to express my sincere appreciation to the Basic and Applied Scientific Research Center of Science College for giving me the opportunity to conduct the practical part research.

\section{REFERENCES}

1. Stevens, P. F. (2001). Onwards. Angiosperm phylogeny website. Avaliable at: http://www. mobot. Org/MOBOT/research/A Pweb.

2. Baldwin, B. G., Wessa, B. L., \& Panero, J. L. (2002). Nuclear rDNA evidence for major lineages 
of helenioid Heliantheae (Compositae). Systematic Botany, 161-198.

3. Panero, J., \& Funk, V. A. (2002). Toward a phylogenetic subfamilial classification for the Compositae (Asteraceae). Proceedings of the Biological society of Washington.

4. Migahid, A. M. (1978). @ Flora of Saudi Arabia: Dicotyledons. University.

5. Mandaville, J. P., \& Mandaville, J. P. (1990). Flora of Eastern Saudi Arabia (p. 482). London: Kegan Paul International.

6. Cronquist, A. (1977). The compositae revisited. Brittonia, 29(2), 137-153.

7. Thome, R. F. (1983). Proposed new realignments in the angiosperms. Nordic Journal of Botany, 3(1), 85-117.

8. Takhtadzhian, A. L., \& Takhtajan, A. (1997). Diversity and classification of flowering plants. Columbia University Press.

9. Kaya, A., ÜNAL, M., ÖZGÖKÇE, F., DOĞAN, B., \& Martin, E. (2011). Fruit and seed morphology of six species previously placed in Malcolmia (Brassicaceae) in Turkey and their taxonomic value. Turkish Journal of Botany, 35(6), 653-662.

10. Jana, B. K., \& Mukherjee, S. K. (2012). Diversity of cypselar features of seven species of the genus Crepis L. Compositae.. Indian Journal of Fundamental and Applied Life Sciences, 2, 51-58.

11. CassInI, A. H. G. (1827). Carlinées-Stéhélinées. In: Cuvier, G. (Ed.). Dictionriaire des Sciences Naturelles. 47: 494 - 513. Paris: Le Normant.

12. Bhar, I., \& Mukherjee, S. K. (2004). Macromorphological and micromorphological study of cypselas in seven species of the tribe Anthemideae (Asteraceae). J. Econ. Taxon. Bot, 28(3), 788-794.

13. Chehregani, A. B. D. O. L. K. A. R. I. M., \& Mahanfar, N. A. T. E. G. H. E. H. (2007). Achene micro-morphology of Anthemis (Asteraceae) and its allies in Iran with emphasis on systematics. International Journal of Agriculture and Biology, 9(3), 486-488.

14. Garg, S. K., \& Sharma, K. C. (2007). Taxonomical significance of the morphological and scanning electron microscopic surface patterns of cypselas in some members of the tribe Heliantheae (Asteraceae). Feddes Repertorium, 118(5-6), 165191.

15. Mukherjee, S. K., \& Nordenstam, B. (2008). Diversity of pappus structure in some tribes of the Asteraceae. Phytotaxonomy, 8, 32-46.

16. Abid, R., \& Alam, J. (2011). Taxonomic significance of cypsela morphology for the tribe Mutisieae (SL)(Asteraceae) from Pakistan. Pakistan Journal of Botany, 43(2), 821826.

17. Bednorz, L., \& Podsiedlik, M. (2013). A study on achene macro-and micromorphological characters of Polish species of the Senecio jacobaea group. Acta Agrobotanica, 66(2).

18. Abid, R., \& Qaiser, M. (2015). Cypsela morphology of Lactuca L. and its allied genera (Cichoreae-Asteraceae) from Pakistan and Kashmir. Pakistan Journal of Botany, 47(5), 1937 1955.

19. Zareh, M. M., Faried, A. M., \& Mohamed, M. H. (2016). Achene wall anatomy and surface sculpturing of Launaea Cass.(Compositae: Cichorieae) with notes on their systematic significance. Korean Journal of Plant Taxonomy, 46(2), 187-198.

20. Candan, F., Uysal, T., Tugay, O., Bozkurt, M., ERTUĞRUL, K., \& Demirelma, H. (2016). The examinations of achene ultrastructural features of section Acrolophus (Centaurea, Asteraceae) via scanning electron microscopy. Turkish Journal of Botany, 40(2), 147-163.

21. Aksu Kalmuk, N., Inceer, H., \& Imamoglu, K. V. (2018). Achene micromorphology of 26 Crepis L.(Asteraceae) taxa from Turkey with notes on its systematic and ecological significance. Botany Letters, 165(2), 292-306.

22. ÖZBEK, M. U., ÖZBEK, F., \& Vural, M. (2018). Achene morphology of the genus Cota J. Gay (Asteraceae) from Turkey and its taxonomic significance. Turkish Journal of Botany, 42(2), 208-223.

23. Ghafoor, A., \& Al-Turki, T. A. (1999). A new Anthemis (Asteraceae) from Saudi Arabia. Edinburgh Journal of Botany, 56(1), 55-59.

24. Shahat, A. A., Ibrahim, A. Y., \& Elsaid, M. S. (2014). Polyphenolic content and antioxidant activity of some wild Saudi Arabian asteraceae plants. Asian Pacific Journal of Tropical Medicine, 7(7), 545-551.

25. Al-Rehaily, A., Thomas, J., Yusuf, M., Mayandy, S., Alfarhan, A. H., El-Sheikh, M. A., \& Alatar, A. (2015). Taxonomy and distribution of two newly recorded genera in Saudi Arabia. Kuwait Journal of Science, 42(3), 158-169.

26. Qari, S. H. E. A. Kamel., \& K. Ali. (2016). Karyotype Criteria of Some Taxa of Asteraceae (Compositae) from Saudi Arabia. IJBPAS, 5(11): 2956-2966.

27. Al-Ahmadi, M. S. (2017). Proteins patterns of eight genera of the Asteraceae family. African Journal of Biotechnology, 16(11), 536-546.

28. Chaudhary, S. A. (2000). Flora of Kingdom of Saudi Arabia 2/3. Ministry of Agriculture and Water, Riyadh.

29. Barthlott, W. (1981). Epidermal and seed surface characters of plants: systematic applicability and some evolutionary aspects. Nordic Journal of Botany, 1(3), 345-355.

30. Barthlott, W. (1990). Scanning electron microscopy of the epidermal surface in plants. Scanning electron microscopy in taxonomy and functional morphology, 41, 69-94. 
31. Stearn, W. T. (1966). Botanical Latin. Nelson, T. \& Sons Lid, London, Edinburgh. London, Edinburgh.

32. Dutta, A.C. (1974). Botany for degree students. Calcutta, Oxford University Press. Delhi Bombay Madras.

33. Dittrich, M. (1985). Morphologische und anatomische Untersuchungen an Bluten und Fruchten der Gattung Carlina (Compositae). I. Botanische Jahrbucher fur Systematik, Pflanzengeschichte und Pflanzengeographie.

34. Abid, R., \& Qaiser, M. (2007). Cypsela morphology of the genus Anaphalis DC.(Gnaphalieae-Asteraceae) from Pakistan. Pak. J. Bot, 39(6), 1897-1906.

35. Abid, R., \& Qaiser, M. (2009). Taxonomic significance of the cypsela morphology in the tribe
Anthemideae (Asteraceae) from Pakistan and Kashmir. Pakistan Journal of Botany, 41(2), 555579.

36. Aytas Akcin, T., \& Akcin, A. (2010). Morphological and anatomical characteristics and taxonomical significance of achene micromorphology of Achillea phrygia and A. gypsicola (Asteraceae), endemic to Turkey. Nordic Journal of Botany, 28(1), 65-73.

37. Akcin, T. A., \& Akcin, A. (2014). Achene micromorphology of seven taxa of Achillea L.(Asteraceae) from Turkey. Bangladesh Journal of Plant Taxonomy, 21(1), 19-25.

38. Bremer, K. (1987). Tribal interrelationships of the Asteraceae. Cladistics, 3(3), 210-253. 